\title{
BRATISLAVSKÁ „KRÁDEŽ“ SVÄTÉHO GRÁLU. REKONŠTRUKCIA INSCENÁCIE WAGNEROVHO PARSIFALA V SLOVENSKOM NÁRODNOM DIVADLE Z ROKU 1935
}

\author{
ROBERT BAYER
}

Divadelný vedec, publicista a prekladatel'

\begin{abstract}
Abstrakt: Štúdia sa venuje dramaturgii neskororomantického vrcholného diela Richarda Wagnera v Slovenskom národnom divadle počas éry Karla Nedbala. Popri Zlate Rýna (1928) a Tristanovi a Izolde (1934) sa zameriava v prvom rade na inscenačnú analýzu Parsifala (1935), posledného javiskového opusu Richarda Wagnera skomponovaného pre festivalové divadlo v Bayreuthe. Reflektujúc sporé archívne materiály, dokladujúce tento jedinečný a dodnes neopakovaný inscenačný počin na opernom javisku SND, sa autor snaží rekonštruovat dramaturgický zámer dirigenta Karla Nedbala a režiséra Bohuša Vilíma v scénografii L’udovíta Hradského, ktorá vykazuje jasné estetické vplyvy reformátorov wagnerovskej scénickej poetiky, Adolpha Appiu a Alfreda Rollera. Expresionistická scénografia nie je síce v európskom inscenačnom kontexte roku 1935 žiadnou estetickou senzáciou, v kontexte mladého súboru opery SND je však dôkazom jeho umeleckej ambicióznosti a húževnatosti. Autor sa zamýšla nad možnými prekážkami a zložitost̉ami inscenačného procesu, akými sú podmienky hudobného naštudovania, technická vybavenost javiska či umelecký preklad libreta, a to najmä vo vzt̉ahu k problematike dramaturgie diel tzv. vel'kého Wagnera. Štúdia spracúva ohlasy dobovej opernej kritiky a približuje reakcie na výkony interpretov jednotlivých postáv. Text je koncipovaný ako pokus o inscenačnú historiografiu, s uvedomením si nástrah tkvejúcich v subjektívnosti dobovej umeleckej kritiky.

Klúčové slová: Richard Wagner, Parsifal, Slovenské národné divadlo, Ludovít Hradský
\end{abstract}

Novodobej opernej dramaturgii Slovenského národného divadla po roku 1945 vyčítali doboví kritici nejeden dlh. Popri absencii prominentných opusov francúzskej grand opery, drammy per musica talianskeho, respektíve anglického baroka, ale aj širšieho francúzskeho repertoáru utkvejú najmä chýbajúce tituly neskorého romantizmu a klasickej moderny nemeckej jazykovej proveniencie. Aj letmý pohlad na hracie plány SND od roku 1945 až do súčasnosti navodí dojem, že v segmente opernej literatúry druhej polovice 19. storočia dominuje jedine Giuseppe Verdi a niekol'ko talianskych (Mascagni, Leoncavallo, Puccini) veristov. Do tejto kategórie by sme mohli zaradit’ aj Bizetovu Carmen, považovanú za predvoj verizmu. Popri absencii t’ažiskových diel od Richarda Straussa, Franza Schrekera, alebo z novších od Albana Berga či Arnolda Schönberga (menujúc len tých najprominentnejších), je priam fatálna ignorancia reformátorských hudobných drám Richarda Wagnera (tzv. vel'kého Wagnera), ktoré zohrali dôležitú úlohu v d’alšom historickom smerovaní operného druhu. ${ }^{1}$

\footnotetext{
${ }^{1}$ Operná reforma Richarda Wagnera mala výrazný vplyv na vznik žánru Literaturoper, ale i na tvorbu skladatel'ov z giovane scuola s charakteristickou odnožou už spomínaného tzv. talianskeho verizmu.
} 
Hladanie príčin, resp. vyhodnotenie argumentov, ktorými sa dramaturgovia snažili ospravedlnit túto repertoárovú medzeru (chýbajúca tradícia, nedostatočný zástoj interpretov, finančná nákladnost' inscenácií), by si zaslúžilo samotnú štúdiu. Predmetom tohto textu je skôr pohlad do dejín SND od neskorých dvadsiatych do prvej polovice tridsiatych rokov minulého storočia, počas ktorých mladý operný súbor prvej divadelnej scény na Slovensku ponúkol svojim divákom sporadicky i diela $\mathrm{z}$ - dnes už dramaturgiou Opery SND chronicky vytesňovaného - repertoáru hudobných drám Richarda Wagnera. Boli to Rýnske zlato (Das Rheingold) v réžii Bohuša Vilíma a v hudobnom naštudovaní Oskara Nedbala z roku 1928, ktorý siahol zrejme po verzii so zmenšeným orchestrálnym obsadením (tzv. Coburger Fassung), autorizovanej samotným Richardom Wagnerom², d’alej hudobná dráma, resp. ako „dej“ (Handlung) nadpísaný Tristan a Izolda v hudobnom naštudovaní Karla Nedbala a réžii Bohuša Vilíma z roku 1934, a napokon o rok neskôr Parsifal, taktiež v naštudovaní Karla Nedbala a Bohuša Vilíma. Obaja zamýšl’ali i uvedenie komickej opery (resp. satirickej hry - Satyrspiel) Majstrov spevákov norimberských (Meistersinger von Nürnberg), to však už vzhladom na tragicky turbulentnú politickú situáciu, následkom ktorej bol Karel Nedbal donútený opustit’ v novembri 1938 Bratislavu, nemohlo byt’ zrealizované. V našej štúdii sa obmedzíme na rekonštrukciu inscenácie Parsifala, ktorá je spomedzi spomenutých troch inscenácií diel Richarda Wagnera na javisku SND nielen najviac zdokladovaná, ale je i svedkom odvážnych umeleckých a dramaturgických ambícií vtedajšieho vedenia opery a jej mladého ansámblu.

Na divadelnom plagáte k premiére 29.3. 1935 so začiatkom o siedmej hodine večer je uvedenie inscenácie Wagnerovho Parsifala ohlásené nasledovne:

Richard Wagner: Parsifal, slávnostná opera v 3 dejstvách. ${ }^{3}$ Slová i hudbu napísal Richard Wagner. Český preklad J. Vymětal. Dirigent Karol Nedbal. Réžia Bohuš Vilím. Nová dekoračná výprava: G. Wintersteiner a J. Hradský. Parsifal: G. Graarud a. h., Klingsor: Karol Zavřel, Gurnemanz, rytier sv. Grálu: Arnold Flögl, Kundry: Maria Safierová, Král' Titurel: Zdenko Ruth-Markov, Amfortas, jeho syn: Boris Archipov a. h., I. rytier sv. Grálu: František Hájek, II. rytier sv. Grálu: Karol Kalaš, I. panoš: Lida Clementisová a. h., II. panoš: Erna Šimandlová a. h., III. panoš: Jozef Mareček, IV. panoš: Jozef Mráz, Kvetinové dievky: Marta Ratajová a. h., Viera Šnydrová a. h., Erna Šimandlová a. h., Lida Clementisová a. h., Zita Frešová a. h., Maria Čverdélyová a. h., a dámsky zbor a. h.. Rytieri sv. Grálu. Zbrojnoši. Panoši. Dejište: Hora Montsalvat a Klingserova čarodejná záhrada. Účinkuje chlap. sbor štát. reálky Dirigent prof. A. Dočkalová. Zosilovacie zariadenie láskave zapožičala a inštalovala firma Philips, Bratislava.

\section{Stav bádania a prameňov}

Rekonštrukcia inscenácie na základe dobových prameňov je pomerne málo pertraktovanou bádatel'skou odnožou teatrológie, a to napriek množiacim sa pokusom

\footnotetext{
${ }^{2}$ Coburské divadlo malo s Richardom Wagnerom vynikajúce vztahy. O licencie pre uvedenie Wagnerovych diel sa pokúšalo relatívne skoro po ich vzniku. Po úspechu zmenšenej verzie Rienziho vznikli onedlho i úpravy d’alších diel. 123 inštrumentalistov Zlata Rýna, ktoré, mimochodom, ešte nebolo koncipované pre zakrytý orchester, zredukovali kapelníci divadla v Coburgu na 42 . Táto verzia existovala v roku bratislavského naštudovania len vo forme adaptácií pre jednotlivé inštrumentálne party.

${ }^{3}$ Richard Wagner nečlení svojho Parsifala na "Akte“ (dejstvá), ale na „Aufzüge“ (výstupy). Z tohto dôvodu používame v štúdii korektný preklad „výstup“.
} 
o (často otáznu a z divadelného hl'adiska problematickú) rekonštrukciu ikonických inscenácií, najmä na operných javiskách. ${ }^{4}$ Predkladaná štúdia vyhodnocuje performatívne aspekty predstavení, snaží sa však viac zachytit’ a analyzovat' hermeneutický kontext inscenácie.

Hermeneutický a performatívny aspekt inscenácie sú navzájom prepojené. Na jednej strane je operné predstavenie jedinečné svojimi naratívnymi prostriedkami aj interakciou medzi javiskom a hl'adiskom, zároveň je obmedzené dlžkou trvania. Operné predstavenie odkazuje samo na seba, pričom u divákov vyvoláva najrozličnejšie reakcie. Na druhej strane však disponuje aj hermeneutickou úrovňou, ktorá chce inscenáciou niečo povedat', interpretovat' či vyložit'. Subjektivita diváckej epistémy vo vnímaní predstavenia sa môže i nemusí prekrývat' s inscenačným a dramaturgickým zámerom realizačného tímu. Fascinujúca jedinečnost’ operného predstavenia tak spočíva i vo vysokej miere subjektivity dojmov, ktoré u publika vyvolávajú reakcie najrôznejšieho typu. ${ }^{5}$ Rekonštrukcia historickej inscenácie, či už v teoretickej bádatel'skej rovine alebo v praktickej javiskovej podobe, je odkázaná na pramene v podobe režijnej knihy, videozáznamu, scénických a kostýmových návrhov, divadelných fotografií. O tvare hudobného naštudovania referujú dirigentské partitúry, notové party a klavírne výtahy. Samozrejme, nezanedbatel’ná je i dobová (odborná) kritika, hodnotiaca jednotlivé predstavenia.

Pri výskume prameňov k inscenácii Wagnerovho Parsifala v SND narazil autor tejto štúdie na niekol'ko problémov, z ktorých sa najzávažnejšími ukázali byt’ chýbajúca režijná kniha a dirigentská partitúra. Z materiálov, ktoré by dokladovali a dokumentovali prípravu a realizáciu tejto inscenácie, sa v Archíve Divadelného ústavu v Bratislave zachovali len skice scénických návrhov k druhému výstupu vyhotovené tušom a akvarelom z roku 1932 a dve vel'koformátové mal'by datované rokom 1935 (taktiež tuš a akvarel). Prvá zobrazuje pravdepodobne sálu rytierov sv. Grálu z druhého obrazu prvého výstupu so stojacim Gurnemanzom v pravom dolnom rohu, druhá zase lesnú čistinu s hradom sv. Grálu v pozadí a s dvoma postavami v l’avej hornej časti (Parsifal a Gurnemanz?) z prvého obrazu prvého výstupu alebo z finále tretieho výstupu. ${ }^{6}$ Ich autorom je scénograf L'udovít Hradský (na divadelnom plagáte mylne uvedený ako J. Hradský).V archíve SND sú uložené štyri čiernobiele fotografie $\mathrm{z}$ predstavenia.

V Zbierke inscenácií Divadelného ústavu Bratislava sa nachádza inscenačná obálka, v ktorej sú archivované kritiky inscenácie, uverejnené v periodikách L’udo-

${ }^{4}$ Pri príležitosti 50. výročia Salzburského vel'konočneho festivalu (Salzburger Pfingstspiele) reinscenovala Vera Nemirova na jar roku 2017 Wagnerovu Valkýru, režírovanú v roku 1967 Herbertom von Karajanom v originálnej scénografii Günthera Schneidera-Siemsena. Opera v Linzi mala na jeseň 2018 v repertoári legendárnu bayreuthskú inscenáciu Tristana a Izoldy v réžii Heinera Müllera z roku 1993, ktorú v roku 2017 zaradil intendant lyonskej opery Serge Dorny spolu so Straussovou Elektrou Ruth Berghausovej (premiéra v Drážd’anoch v roku 1986) a Monteverdiho Korunováciou Poppey v réžii Klausa Michaela Grübersa (premiéra na festivale v Aix-en-Provence v roku 1999) na program festivalu „Memoires“ (Spomienky), pripomínajúc tak - podla Dorneho slov - spektakulárne inscenácie operných dejín.

${ }^{5} \mathrm{~K}$ problematike estetiky performatívnosti pozri FISCHER-LICHTE, Erika. Ästhetik des Performativen. Frankfurt nad Mohanom : Suhrkamp 2004. ISBN-10 9783518123737.

${ }^{6}$ Skutočnost', že ide o prvý výstup, by mohol podporit kostým postavy nal’avo, ktorú čiastočne zakrýva nekolorovaná, očividne staršia mužská postava. V poslednom výstupe totiž prichádza na scénu Parsifal, zocelený a nobilitovaný v boji s čarodejníkom Klingsorom, v zbroji, zatial' čo tu je ako Parsifal identifikovaná postava v chlapčenskom kostýme „naivného prostáčika“ (reiner Tor). 
vá politika, Slovenská politika, Slovák a v denníku karpatských Nemcov Grenzbote (Hraničný posol), písanom po nemecky a v švabachu. Chýbajú bližšie informácie o jednotlivých interpretoch a interpretkách, pričom najväčším problémom bola nejasnost' okolo interpretky Kundry. Divadelné plagáty z premiéry a tiež z reprízy 13. 4. 1935, v ktorej rolu Parsifala pohostinsky alternoval člen Viedenskej štátnej opery Josef Kalenberg, uvádzajú ako Kundry Mariu Safierovú. Recenzent Ivan Ballo, ktorého premiérová kritika vyšla v Slovenskom denníku a ktorý sa zrejme zúčastnil i všetkých repríz, však hovorí o Marii Řezníčkovej. O Řezníčkovej píše v recenzii z premiéry aj prispievatel' Ludovej politiky. Podobne Karel Nedbal vyzdvihuje vo svojich pamätiach výlučne Řezníčkovú, pričom o Safierovej sa nezmieňuje. Vysvetlenie je prosté. Podla Českého hudobného slovníka osôb a inštitúcii ${ }^{7}$ sa mezzosopranistka Marie Řznníčková v časovej blízkosti bratislavského Parsifala vydala, takže ju niektorí kritici hodnotili pod jej dobre známym dievčenským menom, pod ktorým neskôr vystupovala i na javiskách v Brne a v Prahe.

\section{K problematike významu Wagnerovho žánrového označenia „Bühnenweihfestspiel“ a jeho prekladu do slovenčiny}

Denné plagáty premiéry a repríz v SND označujú Wagnerovho Parsifala (v preklade Josefa Vymětala) nie celkom presne ako „slávnostnú operu“, kritik Ivan Ballo dokonca prekladá termín Bühnenweihfestspiel nesprávne ako „slávnostnú operu na zasvätenie javišta“a".

V pôvodnom Wagnerovom žánrovom označení, ktoré je v dejinách opery jedinečné, je obsiahnutých niekol'ko pojmov a významov. V prvom rade označuje "Spiel“ ako hru vo význame divadelnej akcie, ktorá sa môže popri opere vztahovat’ aj na iné formy drámy. „Festspiel“ je teda hra určená pre slávnost', mimoriadnu príležitost', $\mathrm{v}$ tomto prípade konkrétne pre slávnost’ divadelného festivalu v Bayreuthe, kde nechal Richard Wagner vystavat festivalové divadlo, ktoré malo spĺn̆at ním minuciózne sformulované estetické nároky pri inscenovaní jeho javiskových diel. Pojem „Weihe“, ktorý sa do slovenčiny doslovne preložit nedá, konotuje sakrálnu, „posvätnú" akciu a je rozšírením slovného spojenia "slávnostná hra“, ktorým Wagner označoval svoj štvordielny cyklus Nibelungov prsteň. Slovo „Bühne“ prekladáme do slovenského jazyka ako javisko.

Parsifal je jediným dielom Richarda Wagnera, ktoré vzniklo až v dobe existencie festivalového divadla v Bayreuthe, teda už s praktickými akustickými skúsenostami z predchádzajúcich predstavení. Parsifal tu mal svetovú premiéru 26. 7. 1882 vo Wagnerovej inscenácii. Po prvýkrát sa opona vo festivalovom divadle otvorila inscenáciou Zlata Rýna - prvej zo štyroch častí Wagnerovej cyklickej hudobnodramatickej ságy o Nibelungoch - 13. 8. 1876. Javisko v bayreuthskom festivalovom divadle Richarda Wagnera bolo teda, ak chceme, „zasvätené“ o šest' rokov skôr, a to prvým tamojším prevedením Prsteňa Nibelungovho. Parsifala koncipoval Wagner ako dielo určené pre zvláštnu príležitost', počas ktorej sa mal divák v slávnostnom duchu pozdvihnút nad každodennost' a zažit’ „posvätnú“ atmosféru. Festivalové divadlo bolo

\footnotetext{
${ }^{7}$ Pozri http://www.ceskyhudebnislovnik.cz/slovnik/.

${ }^{8}$ BALLO, Ivan. K dnešnej premiére „Parsifala“ na Slov. národnom divadle. In Slovenský denník, roč. 18, č. 62, s. 5, 14. 3. 1935.
} 
pre takéto sakrálne a ritualizované predstavenie hudobnej drámy („Musikdrama“) považované za obzvlášt výnimočné miesto („geweiht“"). Sakrálny bol nielen námet z krestanskej mytológie, ale aj štýl inscenovania, ktorý Richard Wagner označoval ako „princíp posvätnej jednoduchosti“ („Prinzip der weihevollen Einfachkeit“9). Interpreti, ale i diváci mali počas predstavenia zažit’ stav „posvätnej odt’ažitosti od sveta“10. Takáto „posvätnost“" mala podl'a Richarda Wagnera spôsobit,, že každý robil to, čo chcel, avšak - s intuíciou pre morálku a etiku - to „správne“. Takýto stav nazýval Richard Wagner „anarchiou“11 , ktorú vonkoncom nechápal negatívne. „Bühnenweihfestspiel“ by sme teda mohli azda najsprávnejšie preložit’ slovným spojením „posvätná slávnostná hra (pre javisko)“.

Vo svojej koncepcii hudobnej drámy videl Wagner návrat $k$ antickej tragédii. Previazanie umenia a náboženstva $\mathrm{v}$ akte jej uvádzania bolo jednou $\mathrm{z}$ najesenciálnejších inšpirácií jeho koncepcie hudobného divadla ako drámy ideí („Ideendrama“). Podl’a Wagnera čerpalo antické divadlo svoju dôstojnost’ a výpovednú silu z prepojenia na kult, pričom sám seba vnímal ako toho, kto má takúto funkciu divadla obnovit pre súčasného diváka. Georg Oswald Bauer, dlhoročný hovorca festivalu Richarda Wagnera, vo svojej monumentálnej dvojzväzkovej monografii o dejinách Bayreuthských slávností konštatuje: „Sprostredkovanie poznania, sebapoznania, vnímavý pochop motivovaný láskou, $\mathrm{v}$ tomto všetkom spočival podla neho [Wagnera] zmysel a význam gréckeho divadla." ${ }^{12}$

Richard Wagner vyčítal svetu chýbajúcu morálku. Proti rozmáhajúcemu sa egoizmu malo vystúpit umenie a náboženstvo: materiálne orientovanej dobe ponúkol Wagner v Parsifalovi myšlienku spásy v akte súcítenia ako základného fundamentu humanizmu. „Len láska koreniaca a prejavujúca sa v súcítení môže nadobro zlomit’ svojvôlu, iba spásu prinášajúca krest’anská láska, ktorá v sebe zahŕňa vieru, nádej a lásku samotnú “13, tak by sa dala zhrnút’ centrálna dramaturgická myšlienka Parsifala. Wagnerova afinita ku krestanskej mystike na sklonku jeho života nezostala bez kritickej odozvy. Nie je vylúčené, že to bol práve Parsifal, ktorý obrátil ateistického Friedricha Nietzscheho, autora Antikrista a syna evanjelického farára, niekdajšieho horlivého prívrženca Wagnerovho umenia a estetiky, v jedného z najzapálenejších a najprominentnejších skladatel'ových kontrahentov: „Posledné slová, ktoré mi W[agner] adresoval, sú napísané ako venovanie na jednom peknom exemplári Parsifala: ,Môjmu drahému priatelovi Friedrichovi Nietzschemu. Richard Wagner, vrchný cirkevný radca.' Presne v tom istom momente k nemu dorazila moja kniha ,Menschliches Allzumenschliches', ktorú som mu poslal - a tým bolo všetko jasné, ale aj všetko ukončené." ${ }^{14}$

Napriek irónii vo venovaní adresovanom Nietzschemu sa Richard Wagner neštylizoval do pozície zakladatel’a nového náboženstva. Fundamentálny rozdiel me-

${ }^{9}$ MILLENKOVICH-MOROLD, Max. Cosima Wagner: ein Lebensbild. Lipsko : Philipp Reclam, 1937, s. 252. Preklad textov z nemeckého jazyka Robert Bayer.

${ }^{10}$ Cosima Wagner v liste Engelbertovi Humperdinckovi, 25. 8. 1896. Pozri HUMPERDINCK, Eva. Engelbert Humperdinck in seinen persönlichen Beziehungen zu Richard Wagner - Cosima Wagner - Siegfried Wagner dargestellt am Briefwechsel und anderen Aufzeichnungen: Band 1. Mainz : Schott 1996, s. 263. ISBN 978-3-920388-50-2.

${ }^{11}$ WEINGARTNER, Felix. Bayreuth (1876 - 1896). Berlín : Fischer, 1897, s. $44 \mathrm{f}$.

${ }^{12}$ BAUER, Oswald Georg. Die Geschichte der Bayreuther Festspiele 1850-1950 : Band I. Berlín, Mníchov : Deutscher Kunstverlag, 2016, s. 159. ISBN 978-3-422-07343-2.

${ }^{13}$ MACK, Dietrich. Bayreuther Inszenierungsstil (1876 - 1976). Mníchov, 1976, s. 9.

${ }^{14}$ List adresovaný Lou von Salomé, 16. 7. 1882. Pozri http://www.nietzschesource.org/\#eKGWB/BVN1882,269 [cit. 20. 1. 2019]. 
dzi umením a náboženstvom videl v tom, že na rozdiel od náboženstva, ktoré vedie $\mathrm{k}$ viere, privádza umenie človeka k poznaniu. Čistý a naivný prostáčik („der reine Tor“) Parsifal ${ }^{15}$ musí prejst' tažkú cestu, aby dosiahol poznanie. Ako dramaturgická kostra tejto paradigmy slúžila Wagnerovi tzv. Prodikova bájka, ktorá je príbehom o rozhodovaní sa hrdinu medzi zlom a dobrom, známa aj pod názvom „Herkules na rázcesti" . V tejto bájke rozpráva filozof Prodikos o mladom Herkulovi, ktorému sa na rázcestí zjavia dve ženy. Virtus, cnost', v jednoduchom oblečení mu sl'ubuje strmú a tŕnistú cestu za úspechom, ktorá mu zaručí slávu a nesmrtel’nost' - v zmysle krestanskej mystiky cestu do neba. Voluptas, žena kyprých tvarov, mu zase ponúka cestu posiatu ružami, pozemské rozkoše a život v blahobyte. Ten však v antike viedol k priemernosti, k životu bez hrdinských činov a v krestanstve do pekla a k smrti. Ruže sú pritom symbolom vanitas, pominutelnosti a bezcennosti pozemskej krásy. Táto bájka názorne približuje otázku eticky správneho rozhodovania sa. Už v období stredoveku boli podobné morality vyjadrované divadelnými predstaveniami. Tento dramaturgický skelet je divadelne nesmierne účinný a u Richarda Wagnera sa po prvýkrát objavil už v romantickej opere Tannhäuser. Jej titulný hrdina je trýznený polyamoriou $\mathrm{k}$ bohyni lásky a umenia Venuši a k svätici Elisabeth, s ktorou splynie len vykročením z fyzického sveta po smrti. ${ }^{16} \mathrm{~V}$ Parsifalovi sa teda Wagner neobrátil k moralizovaniu skrz obrazy krestanskej mystiky. Príbeh o Parsifalovi by sa dal chápat' ako zavŕšenie jeho celoživotného hl’adania ideálov cnosti, mravnej čistoty a eticky správneho rozhodovania sa, využívajúc pri tom inšpirácie z krestanskej a hinduistickej, respektíve budhistickej náboženskej mystiky. ${ }^{17}$

\section{„Krádež“ svätého Grálu}

Posvätná slávnostná hra Parsifal nemala nikdy opustit javisko festivalového divadla v Bayreuthe. Richard Wagner si neželal, aby bol Parsifal inscenovaný pre zábavu na iných javiskách. Parsifalovská moralita o vykúpení vykupitela mala svojou exkluzivitou prepožičat' bayreuthskej divadelnej svätyni nimbus sakrálnosti, ktorý mal publikum podla vzoru náboženských pútnických miest uviest' do stavu podobnému duchovnému vytrženiu a umožnit’ mu zažit poznanie. Ritualizované bolo aj predstavenie. Dnes už po prvom výstupe aplaudujú len tí, ktorí nevedia, že kedysi bolo úzom mlčky opustit’ auditórium. Cosima Wagner, manželka Richarda Wagnera a prísna strážkyňa jeho duchovného a umeleckého dedičstva, sa ešte pred vypršaním vtedajšieho autorského monopolu (trvajúceho tridsat’ rokov od skladatel'ovej smrti) márne snažila presadit' v nemeckom parlamente zákon, ktorý by zakazoval uvádzanie Parsifala mimo Bayreuthu. Berlínsky Ríšsky snem jej návrh zamietol s výsmechom ako „lex Cosima“, a to aj napriek tomu, že Richard Wagner bol už v tej dobe štylizovaný do pozície národ-

${ }^{15}$ Týmto pojmom označuje Wolfram von Eschenbach svojho Percevala, ktorý bol Wagnerovým hlavným zdrojom a inšpiráciou pre kompozíciu jeho Parsifala.

${ }^{16}$ Režisér Romeo Castellucci vo svojej polarizujúcej inscenácii Wagnerovho Tannhäusera (premiéra v Bavorskej štátnej opere 21. 5. 2017) vystaval Wolframov monológ v tretom výstupe s mŕtvymi telami Tannhäusera a Elisabeth na katafalkoch v pozadí. Počas jeho spevu prechádzajú telesné pozostatky oboch hlavných postáv rôznymi štádiami rozkladu. S poslednými tónmi opery zostal na katafalkoch už iba prach zosnulých.

${ }^{17}$ Takýto vývoj Wagnerovho uvažovania prepájajúceho etiku s umením dokladuje aj fakt, že zamýšllal skomponovat' hudobnú drámu o Ježišovi Nazaretskom a Buddhovi. Nevedno, či by tieto kompozičné plány zrealizoval. Každopádne sú dôkazom toho, ako intenzívne sa zaoberal kontextom morálky a cnosti v umení. 
ného skladatel'a. Nepomohlo ani orodovanie u nemeckého cisára Wilhelma II., ba ani protestná nóta Cosimy u amerického prezidenta Theodora Roosevelta pri príležitosti prvého naštudovania Parsifala v newyorskej Metropolitnej opere 24. 12. 1903.

Posledné Bayreuthské slávnosti pred vypršaním monopolu na Parsifala v lete 1913 Cosima zanovite zrušila, napriek stému výročiu narodenia Richarda Wagnera. Na prelome rokov 1913 a 1914 sa však rozpútala skutočná parsifalovská horúčka, ktorú vo vile Wahnfried v Bayreuthe nenazývali inak než „krádežou svätého Grálu“. Divadlá sa predbiehali o prvenstvo. Ešte na Silvestra 1913 sa zdvihla opona pre Wagnerovho Parsifala v barcelonskom Gran Teatre del Liceu. Začiatok predstavenia o pol jedenástej večer bol uštipačným bonmotom adresovaným Bayreuthu, ktorý od Barcelony delilo jedno časové pásmo. Na Nový rok 1914 nasledovalo Teatro Comunale v Bologni, ktoré sa po tamojšom prvom talianskom uvedení Lohengrina pasovalo na taliansku baštu wagnerovského umenia. Večer 1. 1. 1914 uviedla Parsifala opera v berlínskom Charlottenburgu, predchodkyňa dnešnej Deutsche Oper. Nasledovali konkurenčná berlínska Hofoper - dnešná Staatsoper unter den Linden (5. 1.), parížska opera v Palais Garnier (4. 1.), milánske Teatro alla Scala (9. 1.), Viedenská dvorná opera - dnes Viedenská štátna opera (14. 1.). V prvej polovici roku 1914 uviedli Wagnerovu poslednú hudobnú drámu na javiskách vyše pät’desiatich európskych operných metropol, medzi inými v Londýne, Benátkach, Drážd’anoch, Mníchove, Hamburgu.

V dobe bez nahrávok, CD, DVD a internetového streamingu bol takýto bezpríkladný ošial' pochopitelný. Parsifala bolo dovtedy možné skutočne vidiet' len v Bayreuthe, kde pedantne a v priam sakrálnej úcte prechovávali pôvodnú inscenáciu, ktorú inscenoval samotný majster skladatel. Dokonca aj Thomas Mann, ktorému bolo takéto mystifikovanie umenia cudzie, musel priznat', že predstavenie počas Bayreuthských slávností v auguste 1909 ho svojím čarom vyviedlo z miery. Parsifal bol vd’aka dramaticky premyslenej kompozícii hudobných harmónií, leitmotívov a zvukových obrazov na svoju dobu skutočne progresívny, novátorský a jedinečný. Niet divu, že sa po ňom prominentné operné scény doslova vrhli.

\section{Parsifal na javisku SND}

„Už sa teda i naša opera dopustila ,lúpeže Grálu', ako stúpenci Bayreuthu, ktorému Richard Wagner bol jedine vyhradil svoje posledné dielo, nazývali predvádzanie ,Parsifala' na mimobayreuthských scénach; už sme teda i u nás počuli dielo, o ktorom Felix Weingartner tak krásne hovorí, že nad ním leží jeseň, nie však jeseň, ktorá znamená úpadok síl a blížiacu sa zimu, že vzplanutie týchto jesenných farieb svedčí o najvyššej sile a cez zimu ukazuje k d'alekej jari'; už sa teda i priestorom Slovenského národného divadla nieslo čisté evanjelium tohto vznešeného diela, tak geniálne syntetizujúceho nové útvary [a] všetko, čo tvorilo význačné črty predparsifalovskej tvorby vel'kého hudobného dramatika“, napísal kritik Ivan Ballo pri príležitosti premiéry Parsifala v SND. ${ }^{18}$

Aj ked' od vypršania autorského monopolu uplynulo už dvadsat' rokov, pripravovaná inscenácia bola vzhl'adom na dramaturgickú exkluzivitu spojená s istými finančnými rizikami. Po troch predstaveniach Tristana a Izoldy spred roka, ktoré vy-

${ }^{18}$ BALLO, Ivan. „Parsifal“ na Slovenskom národnom divadle. In Slovenský denník, roč. 18, č. 75, s. 2, 29. 3. 1935. 
kazovali mizivú návštevnost', hrozilo, že Parsifal sa stane finančným fiaskom. Nota bene, ak pre titulnú postavu Parsifala chýbal v domácom súbore interpret, a teda musel byt' angažovaný host'. V siedmich predstaveniach sa bratislavskému publiku v alternáciách titulnej postavy predstavili Gunnar Graarud (člen Viedenskej štátnej opery, bayreuthský Parsifal a bratislavský Tristan), Josef Kalenberg (dlhoročný člen Viedenskej štátnej opery) a Emil Olšovský (člen Národného divadla v Brne). Orchester SND mal síce skúsenosti s partitúrami hudobných drám Richarda Wagnera, ved' pod vedením Oskara Nedbala naštudoval v roku 1928 Zlato Rýna a v roku 1934 pod vedením Karla Nedbala Tristana a Izoldu, partitúra Parsifala však predstavovala úplne novú výzvu. Antonín Drašar, ktorý bol na post šéfa SND povolaný v roku 1931 ako úspešný riaditel' divadla v Olomouci s úlohou konsolidovat’ zúfalú finančnú situáciu prvej slovenskej divadelnej scény, bol predovšetkým obchodník. V Bratislave preferoval hlavne operetu, ktorej Karel Nedbal vo svojich pamätiach vytýkal lascívnost' a prílišnú revuálnost'. ${ }^{19}$ Je však namieste predpokladat', že aj vd’aka takýmto kasovým tahákom mohol neskôr Nedbal realizovat náročnejšie a umelecky i dramaturgicky ambicióznejšie hudobnodramatické projekty.

\section{Estetické inšpirácie scénografie Parsifala L’udovíta Hradského}

Scénografické reformy v inscenovaní hudobných drám Richarda Wagnera, postulované Adolphom Appiom a realizované Alfredom Rollerom (hlavne počas jeho spolupráce s Gustavom Mahlerom ako riaditelom Viedenskej dvornej opery), sú pri pohl'ade na Hradského scénické návrhy k bratislavskému Parsifalovi neprehliadnutel'né. Hradský bol absolventom Umeleckopriemyselnej školy vo Viedni, ktorej riaditelom bol v tom čase Alfred Roller, v triede profesora Oskara Strnada. Strnad vošiel do dejín inscenačnej praxe ako scénograf, režisér i pedagóg Reinhardtovho semináru vo Viedni. Adolphe Appia, popri Edwardovi Gordonovi Craigovi jeden z najväčších reformátorov európskej divadelnej praxe, rozvinul svoju reformu scénografie na pozadí hudobných drám Richarda Wagnera. Prísne reglementovanému inscenačnému štýlu Wagnerových diel, spočívajúcemu v iluzívnej prospektovej mal'be, vyčítal prílišnú statickost'. Po návšteve jednej z repríz Parsifala v Bayreuthe v réžii Richarda Wagnera pranieroval diskrepanciu medzi dielom a réžiou, zrádzajúcu koncepciu Gesamtkunstwerku, ked’že choreografia postáv na javisku bola silne determinovaná kulisami v prospech zachovania perspektívy. Realistickému scénickému maliarstvu oponoval Appia zavedením pohyblivých praktikáblov, schodov a v neposlednej miere i silou výrazu svetla: len takto architektonicky priestorovo koncipovaná scénografia umožní skutočne živú trojdimenzionálnu hereckú akciu a z javiska, ktoré bolo v 19. storočí koncipované skôr ako pohyblivé maliarske plátno, urobí plnohodnotný trojdimenzionálny priestor. Appiove scénické návrhy a podnety pre svetelnú réžiu, koncipované ako ekvivalent $\mathrm{k}$ hudbe a zároveň ako spojivo medzi hereckou akciou a scénou, ovplyvnili smerovanie vývoja scénografie hlboko do 20 . storočia. ${ }^{20}$

${ }^{19}$ NEDBAL, Karel. Pưl století s českou operou. Praha : Státní nakladatelství krásne literatury, hudby a umění, 1959, s. 223.

${ }^{20} \mathrm{~K}$ problematike Appiových reforiem pozri napr. BEACHAM, Richard C. Adolphe Appia: theatre artist. Cambridge University Press, 1987. ISBN-13 978-0521237680. 
Gustav Mahler a Alfred Roller patrili k prvým divadelníkom, ktorí sa Appiove reformy snažili konzekventne presadit’ na opernom javisku. Mahlerove a Rollerove inscenácie vynikali nielen vysokou mierou prepojenia hudby a scény, ale aj dramatickou logikou a prirodzenostou gesta a mimiky. Podla Ferdinanda Pfohla, „Mahler ako operný dirigent disponoval hlbokým citom pre štýl; s najvnútornejším zmyslom pre scénu pestoval umenie a kultúru výrazu; bol kapelníkom a režisérom v jednom, vykladačom hudby skrz scénu, mysliacim mozgom každého predstavenia.“ ${ }^{21}$

V dostupných scénických návrhoch k Parsifalovi od Ludovíta Hradského je zrejmá inšpirácia expresionistickou estetikou, svetelnou réžiou, aj architektúrou scénografie Appiu a Rollera. Na skicách k druhému výstupu odohrávajúcemu sa v Klingsorovej záhrade, vyhotovených tušom a akvarelom, sú rozpoznatelné koncepcie schodov v Klingsorovej veži a v záhrade s Kvetinovými dievkami. Dalej registrujeme aj pomerne expresionisticky ladenú farebnost’ a v náznakoch i svietenie v pozadí hradieb Klingsorovho hradu, ktorý spolu s vežovitými praktikáblovými stavbami podl’a vzoru tzv. Rollerových veží necháva vyzniet scénu neobyčajne plasticky. Návrhy druhého výstupu koncipoval Hradský energickými tahmi pera a štetca na pozadí expresívne poňatých farieb - purpurovej, oranžovej, tyrkysovej a modrej. Schody a sústava plošín, určených podl'a legendy na pravej strane listu Kvetinovým dievkam, dynamizujú a tektonizujú javisko.

Za povšimnutie stojí datovanie týchto návrhov rokom 1932. Bayreuth mal v tom čase v repertoári ešte stále pôvodného Wagnerovho Parsifala v dekoráciách, ktorých dezolátny stav nútil kulisárov a kostymérov k čoraz častejším opravám. Hradského návrhy tak vznikli dva roky pred pokusom o prvú novú inscenáciu Parsifala v Bayreuthe. Jej scénografom bol práve Alfred Roller - vtedajšej intendantke slávností Winifred Wagnerovej, vdove po Richardovom synovi Siegfriedovi Wagnerovi, ho navrhol sám Adolf Hitler. ${ }^{22}$ Pre značný protest tradicionalistov, ktorí sa za žiadnu cenu nechceli vzdat' pôvodnej inscenácie bayreuthského majstra, mohli byt’ Rollerove zámery zrealizované len čiastočne. ${ }^{23}$

Hradského scénické návrhy rytierskej sály chrámu svätého Grálu a lesnej čistiny s hradom Montsalvat v pozadí poukazujú na odklon od praxe iluzívnej prospektovej mal'by smerom k scénickej abstrakcii. Podobne ako červené stĺpy chrámu so zlatými ornamentmi, aj koruny stromov sa strácajú v povrazisku. Nadobúdajú tak spoločný význam v zotretí hraníc medzi vonkajším a vnútorným: stromy sa stávajú stĺpmi a naopak. Svojou otvorenostou smerom nahor evokujú nekonečnost’ priestoru scenérie (a času) v zmysle Gurnemanzovej repliky z prvého výstupu: „Du siehst mein Sohn, zum Raum wird hier die Zeit" (Vidíš, syn môj, priestorom sa tu stáva čas). Takýto dojem však oslabuje zlatá kupola s krížovými ornamentmi v byzantskom štýle, upevnená na štyroch masívnych zlatých retaziach, ktorá uzatvára priestor nad kruhovým „oltárom“ chrámu rytierov svätého Grálu. Na fotografii z inscenácie, uverejnenej

${ }^{21}$ Cit. podla ECKERT, Nora. Von der Oper zum Musiktheater: Wegbereiter und Regisseure. Berlín : Henschel Verlag, 1995, s. 15. ISBN 9783894872076.

${ }^{22}$ Traduje sa, že Adolf Hitler sa dvakrát pokúšal uchádzat’ u Rollera ako vrchného scénografa Viedenskej dvornej opery o miesto divadelného maliara. Vždy sa však vraj obrátil na schodoch v opere, z rešpektu pred Rollerovou osobnostou.

${ }^{23}$ Viac o tejto téme pozri aj ZAVARSKÝ, Ján. Alfred Roller - novátor a tradicionalista. In Slovenské divadlo, 2017, roč. 65, č. 4, s. 383 - 401. DOI: 10.1515/sd-2017-0023. 


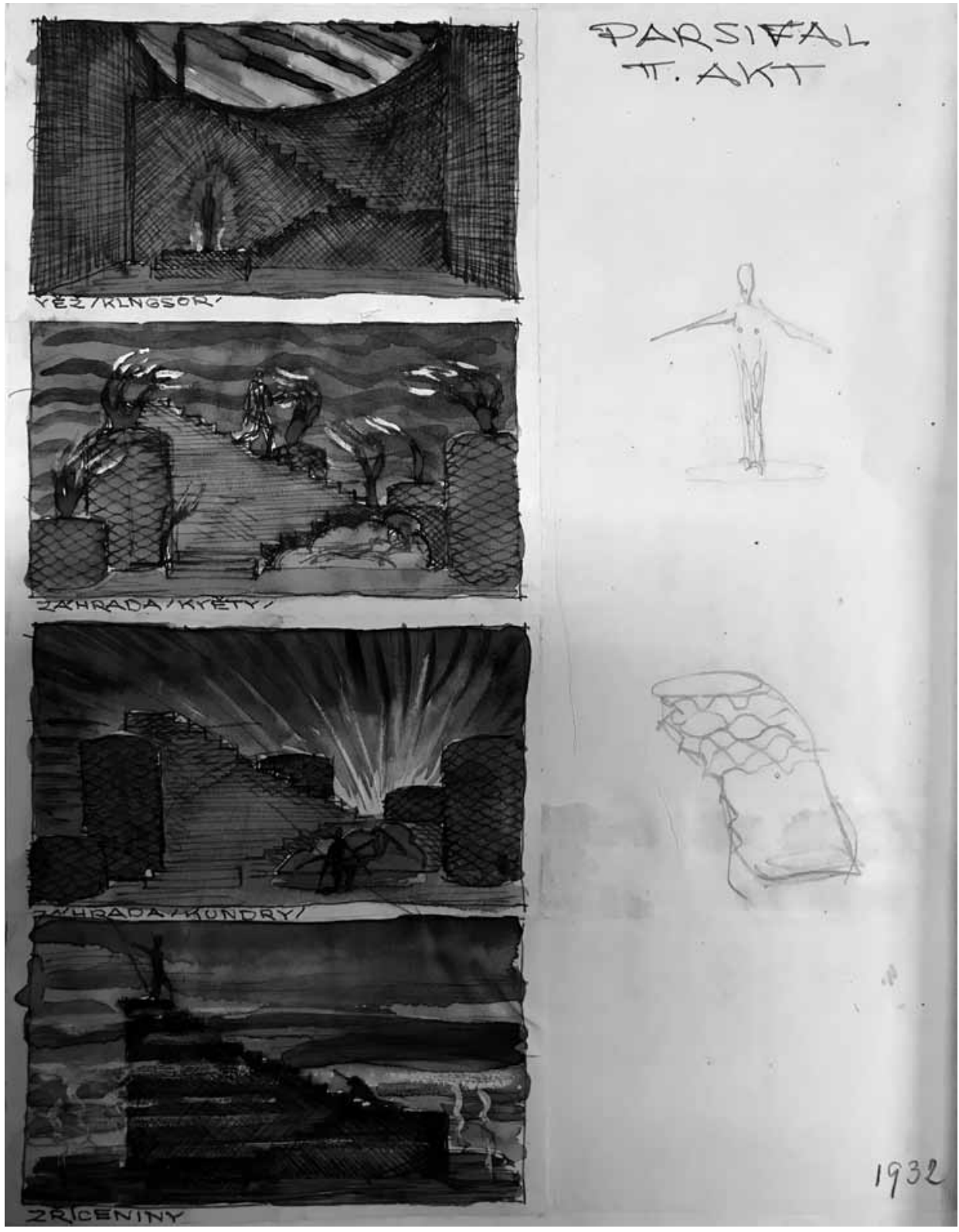

Richard Wagner: Parsifal. Slovenské národné divadlo, premiéra 29. 3. 1935. Scénické návrhy Ludovíta Hradského (1932). Foto Archív Divadelného ústavu Bratislava. 
v najnovšej reprezentatívnej monografii Dejiny slovenského divadla ${ }^{24}$, však zlatá kupola zo scénického návrhu chýba. Je teda pravdepodobné, že výsledná realizácia scény sa Hradského skíc nepridŕžala doslovne. Na pozadí piatich stlípov je navyše vidiet sedem masívnych uzavretých oblúkov. Scéna tak pôsobí viac abstraktne a funkcionalisticky, celkom v zmysle expresionistickej snahy o formálnu jednoduchost', vzdialenej od iluzívne dekoratívneho javiskového vizuálu s dominanciou plošne komponovanej perspektívy ako základného wagnerovského scénografického princípu 19. storočia. Priestorovo neohraničenou sa zdá byt’ aj šikmá, zaoblená plošina lesnej čistiny s expresionisticky stvárneným, priam až bauhausovsky pôsobiacim hradom Montsalvat so žltým horizontom v pozadí, pripomínajúcim tak trochu hrad Walhalla z Ladvenicovho scénického návrhu k bratislavskej inscenácii Zlata Rýna. Hradského výpožička z divadelného fundusu v dôsledku šetrenia finančných zdrojov je vel'mi pravdepodobná, ked’že spomínanú Walhallu pripomína hrad Montsalvat aj na fotografiách z inscenácie. Okružná podesta strácajúca sa za stromami za pravým horizontom zase evokuje známu „Weltenscheibe“ vo forme kruhovej naklonenej plošiny, na ktorej o tridsat rokov neskôr režírovali Wolfgang a Wieland Wagner prvé povojnové bayereuthské naštudovanie Prsteňa Nibelungovho. Wolfgang a Wieland Wagnerovci sú často považovaní za demiurgov tzv. Nového Bayreuthu. Ich koncepcia mala očistit’ Bayreuth od nánosov politicky motivovaných inscenačných (dez)interpretácií z čias 2 . svetovej vojny. Aj z porovnania s bratislavským Parsifalom je však zrejmé, že bayreuthská inscenačná estetika Wielanda Wagnera (Parsifal 1951 - 1958, Prsteň Nibelungov 1952 - 1958, Tristan a Izolda 1952 - 1953) bola skôr štýlovým pokračovaním minimalistickej estetiky „novej vecnosti“" ktorej vývoj prerušila 2 . svetová vojna. ${ }^{25}$

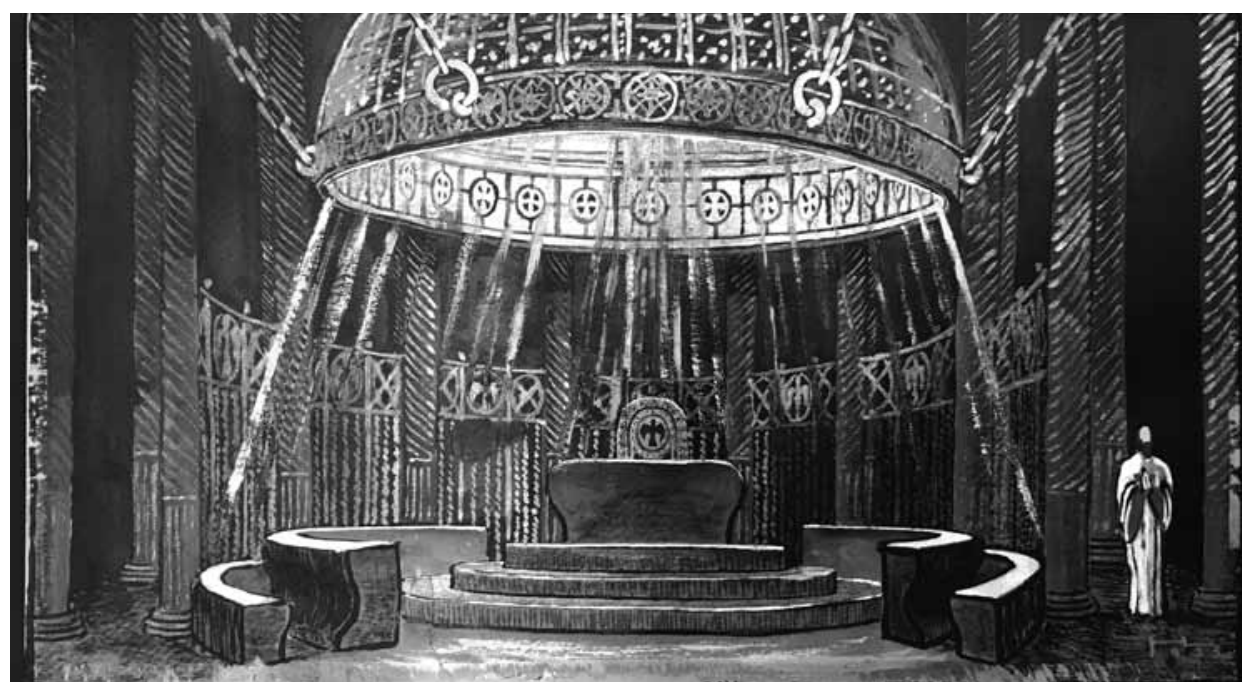

Richard Wagner: Parsifal. Slovenské národné divadlo, premiéra 29. 3. 1935. Scénický návrh Ludovíta Hradského. Chrám rytierov sv. Grálu (1935). Foto Archív Divadelného ústavu Bratislava.

${ }^{24}$ Kol. Dejiny Slovenského divadla I. Bratislava : Divadelný ústav, 2018, s. 362. ISBN 9788081900396.

${ }^{25}$ Skutočne novátorskými boli v Bayreuthe až inscenácie Tannhäusera v réžii Götza Friedricha (1972 1978) a neskôr legendárneho „Prsteňa storočia“ vo fenomenálnej réžii Patricea Chéreaua (1976 - 1980). 


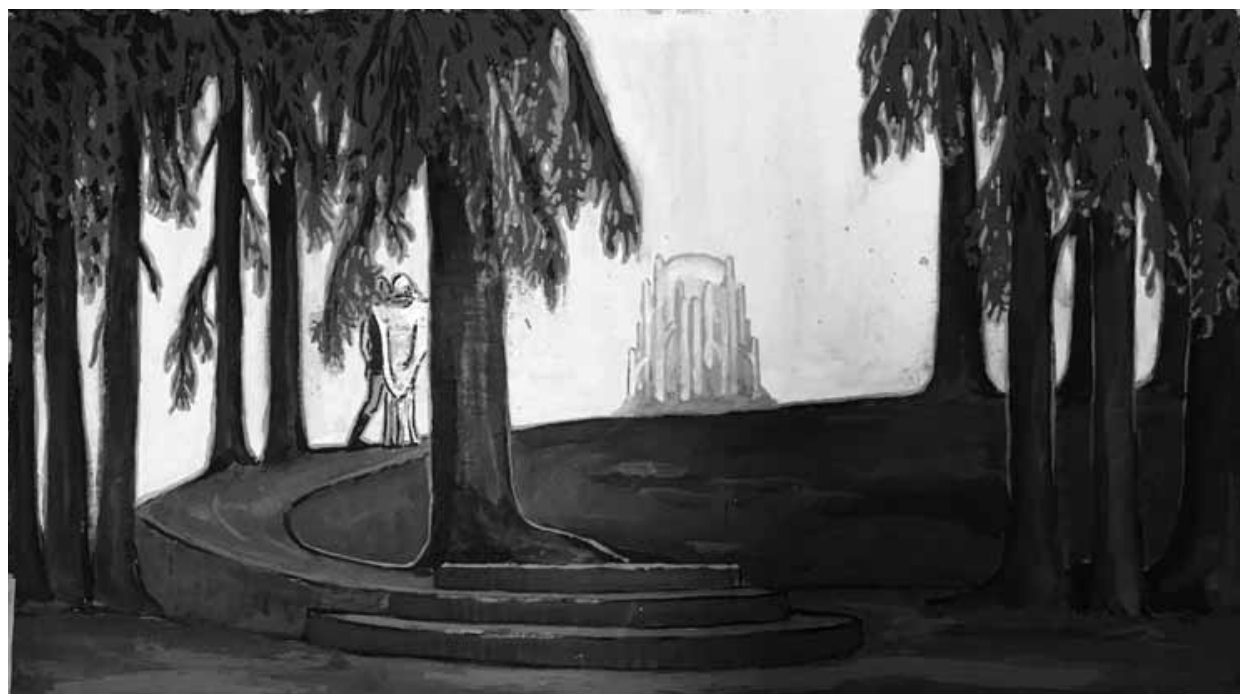

Richard Wagner: Parsifal. Slovenské národné divadlo, premiéra 29. 3. 1935. Scénický návrh Ludovíta Hradského. Lesná čistina, v pozadí hrad rytierov sv. Grálu (1935). Foto Archív Divadelného ústavu Bratislava.

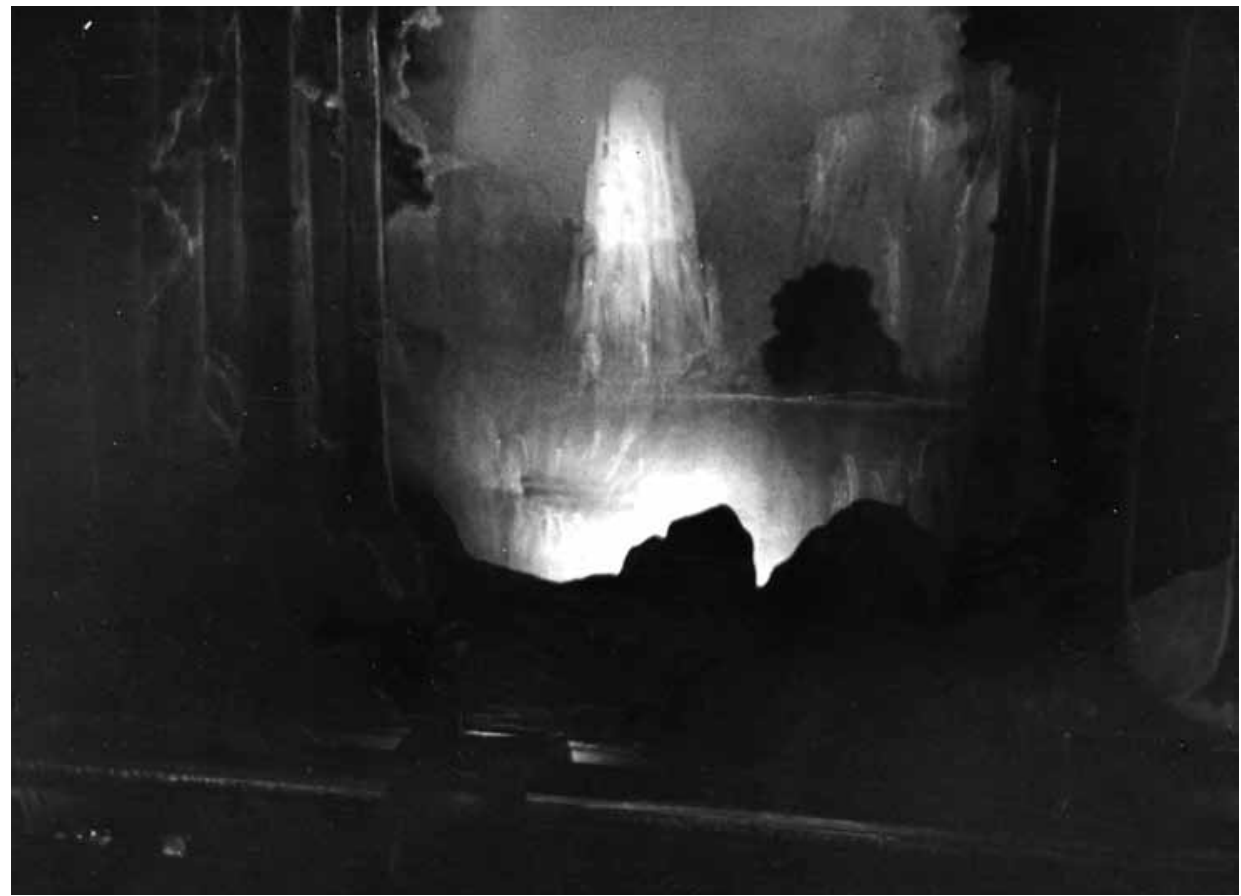

Richard Wagner: Parsifal. Slovenské národné divadlo, premiéra 29. 3. 1935. Tretí výstup. Réžia Bohuš Vilím, hudobné naštudovanie Karel Nedbal. Foto archív Slovenského národného divadla. 
Pohl’ad na tri čiernobiele fotografie bratislavského Parsifala približuje svetelnú réžiu inscenácie. V relatívne tmavej a ponurej scéne nechávajú svetlá vyniknút plastickosti jednotlivých postáv a scény. Jasnejšie osvetlený horizont navodzuje dojem priestorovej hĺbky a nekonečnej dial'avy, najmä na fotografii s étericky pôsobiacou horou Montsalvat, stojacou nad priepastou v pozadí, z ktorej vyžaruje tajomné svetlo. Expresionisticky pôsobiace kulisy akoby náročky zmäkčovalo impresionisticky ladené svietenie, ktoré celej inscenácii zrejme prepožičalo nimbus ezoterickej tajuplnosti. Jej obrazom, na míle vzdialeným od realistickej, perspektivisticky ladenej iluzívnej scénickej mal'by, priznal recenzent Grenzbote „fascinujúcu krásu“. Z takejto inscenačnej poetiky, v ktorej podl’a recenzenta denníka Slovák nadchla najmä scéna odhalenia sv. Grálu, sa dá vydedukovat', že realizačný tím sa k réžii Wagnerovho Parsifala postavil skôr pietne a, odhliadnuc od scénografie, bez hlbších sémantických posunov v čítaní predlohy. Takýto abstrahujúci prístup k scénografii bol však v tej dobe na európskych prominentných operných scénach už relatívne bežný.

\section{Hudobné naštudovanie a réžia}

Absencia režijnej knihy a partitúry s prípadnými poznámkami o tempe, dynamike či škrtoch znemožňuje adekvátnu rekonštrukciu týchto zložiek inscenácie bratislavského Parsifala. Pri ich hodnotení sa preto môžeme odvolávat' iba na dobových recenzentov, z ktorých sa ako najerudovanejší javí Ivan Ballo. V Slovenskom denníku publikoval v deň premiéry článok, v ktorom vysvetl'uje hudobnú dramaturgiu Wag-

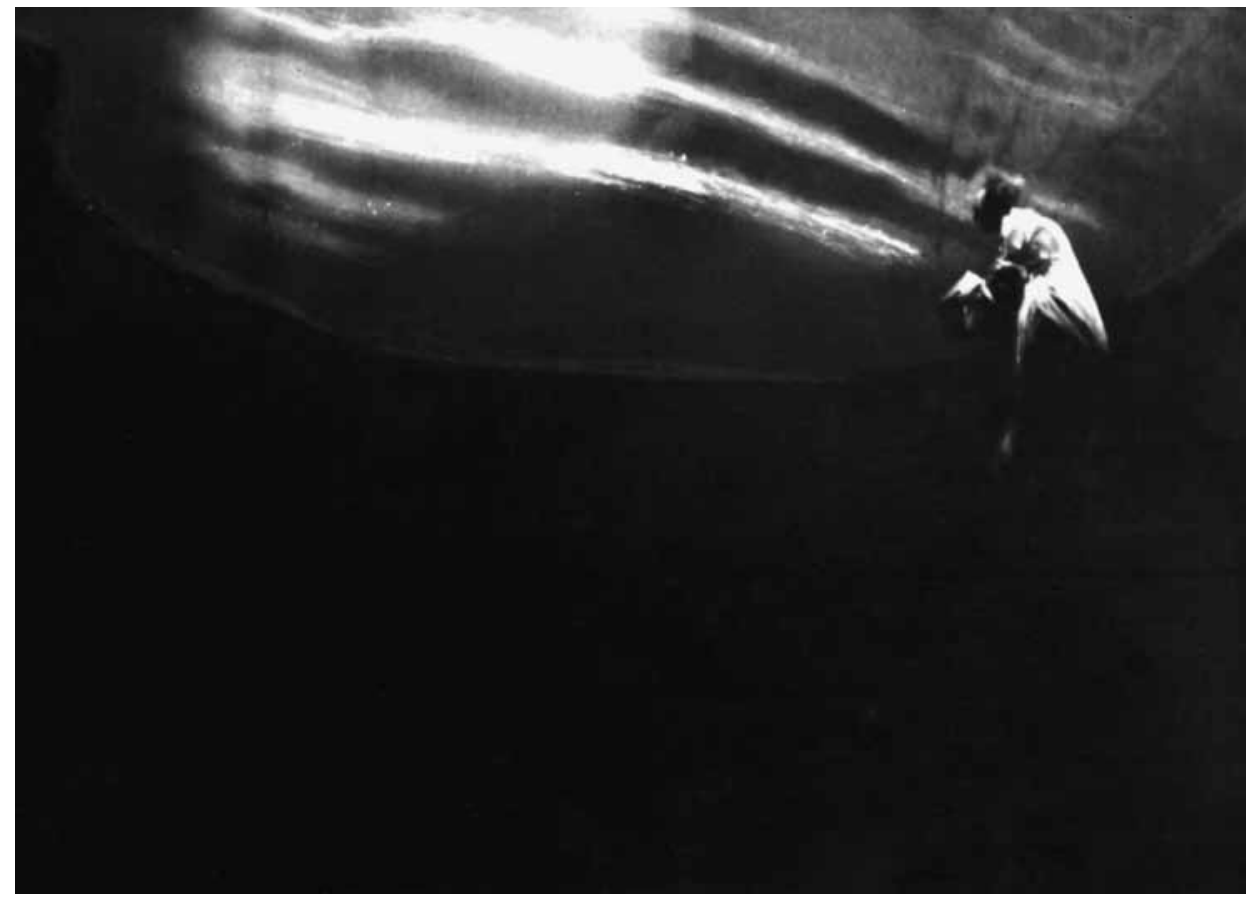

Richard Wagner: Parsifal. Slovenské národné divadlo, premiéra 29. 3. 1935. Druhý výstup. Réžia Bohuš Vilím, hudobné naštudovanie Karel Nedbal. Foto archív Slovenského národného divadla. 


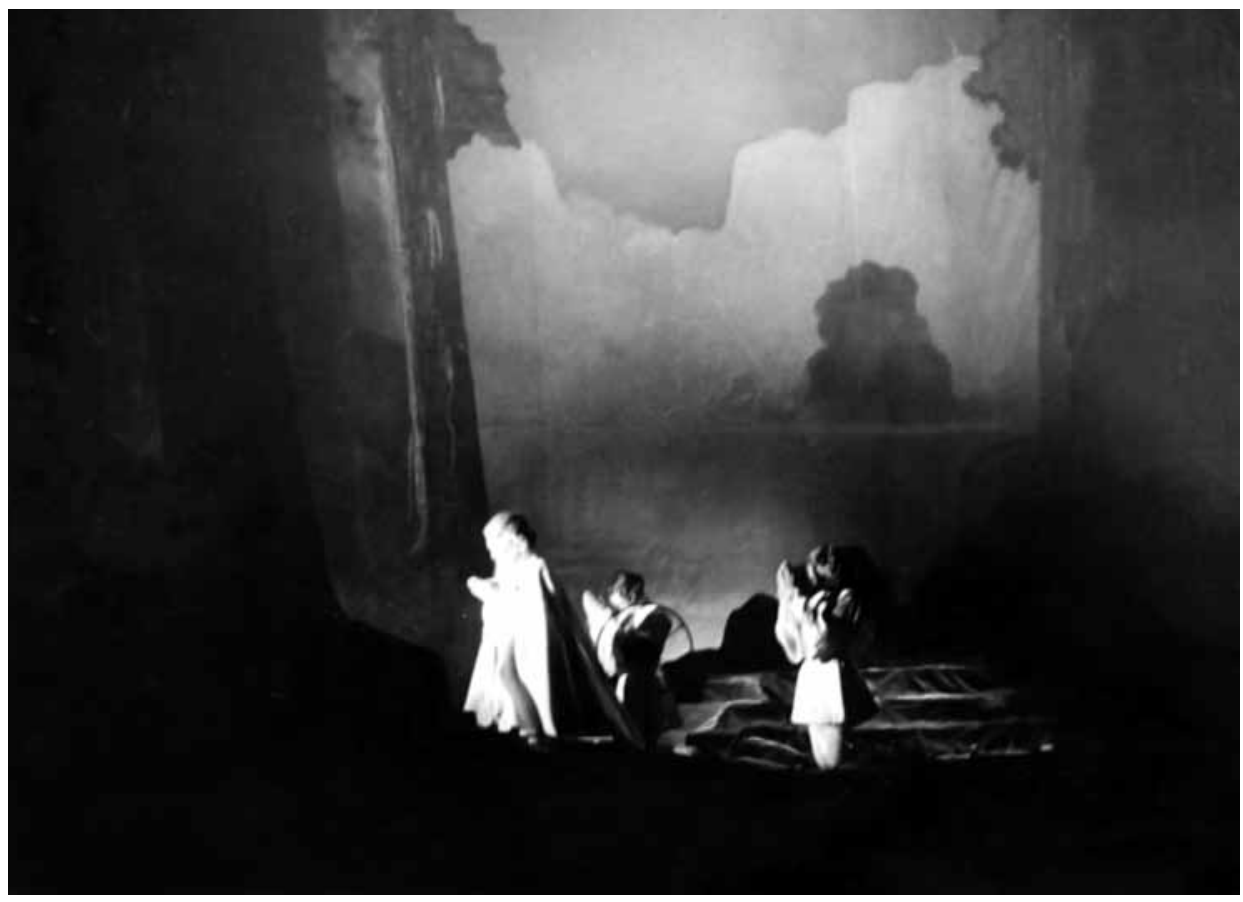

Richard Wagner: Parsifal. Slovenské národné divadlo, premiéra 29. 3. 1935. Prvý výstup. Réžia Bohuš Vilím, hudobné naštudovanie Karel Nedbal. Foto archív Slovenského národného divadla.

nerovho diela. Čitatel’ovi približuje výstavbu hudby, jej novátorstvo i vztłah k textu libreta: „Pre nové úkoly našiel Richard Wagner celkom nové tóny, nie bez vedomého priblíženia k cirkevnej hudbe. Unisonný začiatok predohry, téma Večere Pánovej, je základom vel'kej časti hudby ,Parsifala', z neho sú odvodené témata kopie, súcitu, vykúpenia. Druhé, akordické téma so svojím cirkevným tónom a zbožným vzostupom sexst (saské amen) ${ }^{26}$ je symbolom svätého Grálu; téma hned' naň nadväzujúce, prednášané trúbkami a pozaunami, téma čistého prostáčika [reiner Tor - pozn. R. B.], d’alej výkrik hriešneho stvorenia $s$ kliatbou, rútiacou sa nadol tromi oktávami (pri prvom zjavení Kundry) a konečne lútost’ a túha z hriechu po vykúpení (Žaloba Spasitel'ovi), chromatické téma akordické, ktoré prichádza najprv v hudbe prvej premeny [Verwandlungsmusik, pozn. R. B.] a potom častejšie: všetko hudobné útvary pre „Parsifala' príznačné, nové, úchvatné. (...) A tak je ,Parsifal' v básni i hudbe vpravde etické: drama svedomia a božieho smilovania. ${ }^{27}$ Takéto zhrnutie je samozrejme vel'mi zjednodušujúce, pravdepodobne však prispelo k relatívne dobrej návštevnosti, o ktorej sa Ballo pochvalne vyjadruje v neskoršom článku v Slovenskom denníku. ${ }^{28}$

${ }^{26}$ Konkrétne „Amen“ spievané v Kostole sv. Kríža v Drážd’anoch. Richard Wagner tu pôsobil ako kapelník v Saskej dvornej opere (1843 - 1849).

${ }^{27}$ BALLO, Ivan. K dnešnej premiére „Parsifala“ na Slov. národnom divadle.

${ }^{28}$ BALLO, Ivan. Velké večery opery Slov. národného divadla. In Slovenský denník, roč. 18, č. 78, s. 5, 2. 4. 1935. 
Všetko nasvedčuje tomu, že tak ako réžia rešpektovala režijné poznámky partitúry, tak aj Karel Nedbal zvolil tempá korešpondujúce s dobovým úzom, hlavne tým viedenským, kde bol častým hostom. Škoda, že Ballo nebol dôslednejší a neodstopoval dížky jednotlivých dejstiev, ktoré by nám v porovnaní s relatívne dobre zdokumentovanými dížkami inscenácií bayreuthských predvedení vedeli bližšie priblížit charakter Nedbalovho hudobného naštudovania. Ivan Ballo o ňom napísal: „S celou svojou len a len pre dielo zapálenou oddanostou, hlboko zasvätený v hudobné zloženie i duchovný obsah diela, ho viedol Karel Nedbal, v mocnom stupňovaní od aktu k aktu dávajúc orchestrálnemu partu príkladnú plastiku, sústredenost', monumentalitu výstavby i vel'kú intenzitu výrazu vo všetkých sférach v ,Parsifalovi' sa stretajúcich a hudbou tak úchvatne tlmočených. Kongeniálne dal Karel Nedbal svetu sv. Grála posvätnú velebu; utrpeniu Amfortovmu sžieravú bolestnost; kúzlu Vel'kého piatku božský mier prebúdzajúcej sa jarnej prírody; Parsifalovi tóny jímavej prostoty a čistoty; Kundry spár démonie i zas kajúcnu pokoru; svetu kúzel čarodeja Klingsora dravú zlobu i zas lúbeznú svodnost'. Každý ten register výrazu vždy v pravú chvílu a v pravej miere - všetko bedlive odvážené a v celok organicky zapnuté. Bol to po lanskom nádhernom ,Tristanovi' d’alší vel'ký, nedocenitelný wagnerovský čin Karla Nedbala, rastúceho s každým novým úkolom. Slová sú tu príliš bledé: takého ,Parsifala' v hlboko l'udskom, duchovnelom podaní Karla Nedbala treba zažit!!“29

Aj orchester sa podla Balla presvedčivo vyrovnal s partitúrou. Vyčíta mu jedine drobné nepresnosti v nástupoch. Poznámka o sláčikoch, ktoré svoju podobsadenost' vyrovnávali intenzitou zvuku, nasvedčuje tomu, že Nedbal bol z dôvodu obmedzeného priestoru orchestriska v historickej budove SND nútený zredukovat počet hráčov. Na premiérovom plagáte registrujeme aj odkaz na zosilňovacie zariadenie namontované firmou Philips. Ten nastoluje predpoklad, že zvuk tzv. „Gralsglocken“ bol púštaný z nahrávky. Operný historik Jaroslav Blaho v monografii Dejiny slovenského divadla $I$. v tejto súvislosti dodáva: "Zaujímavostou hudobného naštudovania bolo, že zvuk chlapčenského zboru, ktorý mal zniet’ za scénou (...) sa prenášal pomocou zvukovej techniky do hl'adiska z baletnej sály.“"30

Je pravdepodobné, že réžia Bohuša Vilíma bola koncipovaná staticky a s rešpektom voči skladatelovým režijným poznámkam. Karel Nedbal sa vo svojich pamätiach vyjadril o Vilímových operných réžiách v SND takto: „Za druhej bratislavskej činnosti bohužial' nesplnil všetko, čo sa od neho očakávalo, najmä ked' mu prenikavo zmodernizovaný javiskový aparát dával bohaté možnosti. Ak už v Olomouci mali v práci nad fantáziou prevahu kalkul a rutina, stupňovalo sa v Bratislave spoliehanie na rutinu od réžie k réžii a nakoniec uviazlo na niekol'kých stereotypných klišé, priamo tvrdošijne opakovaných akoby navzdory hlasom kritiky, ktorá sa pri jeho príchode stavala k jeho práci vel’mi kladne. “31 Niet dôvodu si mysliet’, že by Vilímova réžia Parsifala vykazovala revolučný či nebodaj voči dramaturgii diela kritický inscenačný rukopis. Recenzent L’udovej politiky hodnotí Vilímovu réžiu všeobecne ako skvelú. ${ }^{32}$ Podobne pochvalne sa o nej vyjadruje i recenzent Slovenskej politiky,

\footnotetext{
${ }^{29}$ BALLO, Ivan. „Parsifal“ na Slovenskom národnom divadle.

${ }^{30}$ BLAHO, Jaroslav. Hudobné divadlo v rokoch 1928 - 1945. In Kol. Dejiny Slovenského divadla I., s. 365.

${ }^{31}$ NEDBAL, Karel. Prol století s českou operou, s. 239.

${ }^{32}$ Autor neuvedený. „Parsifal“ v SND. In L’udová politika, roč. 11, č. 74, s. 5, 3. 3. 1935.
} 
ked' Vilímovi prisudzuje podiel na tomto „vrcholnom výkone našej opernej scény“33. Recenzia v Slovákovi ide v hodnotení réžie o krôčik hlbšie a taktne, bez uvedenia konkrétnych príkladov, ju kvituje: „Réžia urobila všetko možné, aby súhra bola pokojná a dôstojná." ${ }^{34}$

\section{Osoby a obsadenie}

Nielen pre chýbajúci zástoj domácich hrdinských tenorov, ale tiež s ohl’adom na početnú nemeckú komunitu v Bratislave bolo vedenie SND nútené dovážat aj sólistov, o ktorých sa čítalo v bratislavských kaviarňach v nemeckej či mad’arskej tlači. Gunnara Graaruda malo bratislavské obecenstvo možnost’ spoznat’ už v roku 1934 ako Tristana. Tohto tenoristu by sme dnes mohli významom a slávou prirovnat k súčasnému formátu najväčších operných hviezd. Graarud bol nielen sólistom Viedenskej štátnej opery, na javisku ktorej stvárnil Parsifala dvadsať̌̌est’krát, ale aj častým hostom Bayreuthských slávností, kde naštudoval Siegmunda, Tristana i Parsifala. Vd’aka nahrávke predstavenia $\mathrm{v}$ bayreuthskom festivalovom divadle pod taktovkou Karla Elmendorffa z roku 1928, s Nanny Larsen-Todsen ako Izoldou, je Graarud aj historicky prvým Tristanom zachyteným na zvukovom nosiči. Karel Nedbal naň vo svojich pamätiach spomína ako na družného človeka, ktorý v prestávkach medzi skúškami bavil ansámbel bohatými skúsenost’ami z európskych javísk. Ktovie, či už vtedy dával tento rodený Nór najavo i svoje sympatie s Hitlerovým národným socializmom, ktorého náruživým zástancom bol až to takej miery, že sa ponúkol slúžit’ u Waffen-SS a v posledných dňoch vojny sa hrdo hlásil k tzv. Volkssturmu, s ciel’om posilnit’ zdecimovaný Wehrmacht $\mathrm{v}$ záverečnej fáze 2. svetovej vojny. Bratislavská kritika mu ležala pri nohách už po jeho kreácii Tristana v roku 1934. Zrejme jediný z ansámblu spieval Parsifala po nemecky, ako vyplýva z kritiky v Slovákovi: „,[Graarud] mal prednost’ v tom, že mohol spievat' svoju partiu v pôvodnom verši Wagnerovom. ${ }^{\prime 35}$

Ballo sa pri hodnotení Graaruda vyjadruje o potrebe špeciálnej štúdie, ktorá by vyčerpávajúco reflektovala jeho kreáciu Parsifala v Bratislave. Určite aj vd’aka bohatým skúsenostiam s touto postavou bol jeho výkon „rastúci z preniknutia nielen postavy, ale celého diela, suverénne nachádzal tóny svrchovanej prostoty a výraznosti, ba priam jedinečnosti na vyjadrenie záchvevov duše Parsifala - nevedomého chlapca, i zas s akou vel'korysou prostotou podával Parsifala - rytiera, plne si vedomého bôl'u, ktorý nevedomky zapríčinil, plne si však vedomého i svojho vznešeného poslania vykupitel'ského; v akých vel'kých líniách sa klenul a ako ušlachtile sa niesol jeho bohato diferencovaný, zduchovnelý spev; akú monumentalitu a jednako nenútenú prirodzenost' malo jeho lapidárne gesto; ako sa každé hnutie vnútra zračilo v úspornej a jednako bohatej, ba práve preto takej výmluvnej mimike tvárí. Všetko to rástlo z hudby a jednako bolo slobodné. " ${ }^{36}$ Ballo favorizuje Graarudov výkon i popri alternujúcom Josefovi Kalenbergovi, ktorý viac než hrdinskostou gesta zaujal striedmejšou paletou farby hlasu a civilnejším stvárnením, a Emilovi Olšovskom, ktorý svojimi

\footnotetext{
${ }^{33}$ Autor neuvedený. Wagnerov Parsifal na SND. In Slovenská politika, roč. 16, č. 74, s. 2, 3. 4.1935.

${ }^{34}$ Autor neuvedený. Parsifal. In Slovák, roč. 17 - 1, č. 76, s. 8, 31. 3. 1935.

${ }^{35}$ Tamže.

${ }^{36}$ BALLO, Ivan. „Parsifal“ na Slovenskom národnom divadle.
} 
mäkšími črtami prepožičal Parsifalovi slovanskú srdečnost'. Marie Řezníčková (vyd. Safierová) bola jednou z overených a stabilných síl prvého bratislavského operného súboru. Nedbal si na ňu spomína ako na pracovitú a húževnatú umelkyňu. Aj Ballo píše o jej zápale, s akým brúsila dramatický charakter dvojtvárnej Kundry od reprízy $\mathrm{k}$ repríze.

Zdá sa, že najväčšie potiaže mal Arnold Flögl s rozsiahlou rolou Gurnemanza. Plný zvuk i kovová farba, ktorú vedel nasadit’ aj mäkšie či menej nadnesene, a celkovo harmonickejšie pôsobenie sa u neho dostavili až v predposlednej repríze 24. 4. 1935. Karel Zavřel si podla Ballu na postave padlého rytiera sv. Grálu „zgustol“. Jeho dravost’ i zloba vyznievali presvedčivo i napriek divadelnej hmle, do ktorej bol zrejme druhý výstup s výjavmi z Klingsorovej veže ponorený. Nadšenie kritiky stúpalo od reprízy k repríze tiež pri výkonoch Borisa Archipova ako pôsobivo uboleného Amfortasa a Zdenka Rutha-Markova v postave „velebného“37 Titurela. Podobne aj chlapčenský zbor pod vedením dirigentky Dočekalovej sa predstavil vo vynikajúcej kondícii.

Na rozdiel od Tristana a Izoldy boli predstavenia Parsifala hojne navštívené a podl'a Ballu bolo každé z nich zážitkom. Spomedzi všetkých sa muselo mimoriadne vydarit predstavenie na Bielu sobotu 29. 4. 1935, ked’ vyššie spomínané spevácke kreácie i výkon orchestra podporila atmosféra nadchádzajúceho sviatku Vel'kej noci, tematicky obsiahnutej aj v hudobne sugestívnej scéne kúzla Vel'kého piatku („Karfreitagszauber"), tretieho výstupu Wagnerovho vrcholného opusu.

\section{Záver}

Inscenácia Nedbalovho a Vilímovho Parsifala v SND zostala dodnes neprekonaným dramaturgickým počinom vtedajšieho operného ansámblu. Verva, odhodlanie, odvaha, ale i pracovné nasadenie, s akým sa pustil súbor do jej realizácie, sú aj z dnešného pohl'adu obdivuhodné. Synergia kreatívnych síl na scéne i za scénou tak obdarila vtedajšie bratislavské publikum podmanivo naštudovaným a na tú dobu stále relatívne moderným kusom svetovej hudobnodramatickej tvorby. Napriek tomu, že od Appiových a Rollerových divadelných reforiem už v dobe bratislavskej inscenácie Parsifala uplynuli štyri desatročia a expresionisticky ladené inscenačné estetiky neboli na európskych operných scénach dávno žiadnym scénografickým exotizmom, je bratislavský Parsifal dôkazom toho, aké vysoké boli umelecké, dramaturgické a estetické ambície mladého ansámblu opery SND, ktorý ešte len začínal budovat' svoju tradíciu. Nadšené reakcie divákov zase svedčili o tom, akú dôležitú úlohu zohrala táto inscenácia pri budovaní vzt’ahu bratislavského publika ku svojej prvej domovskej scéne.

\footnotetext{
${ }^{37}$ Tamže.
} 
BRATISLAVA „ROBBERY“ OF THE HOLY GRAIL. RECONSTRUCTION OF WAGNER'S PARSIFAL PRODUCTION AT THE OPERA OF SLOVAK NATIONAL THEATRE (1935)

\section{Robert BAYER}

The study focuses on the dramaturgy of the late-romantic Richard Wagner's masterpiece in the Opera of Slovak National Theatre during the Karel Nedbal era. In addition to The Rine Gold (1928) and Tristan and Isolde (1934), the author focuses primarily on the Parsifal staging analysis - Richard Wagner's last stage production, composed for the Bayreuth Festival Theatre. The text reflects inadequate archive materials that document this unique and - as until today - unprecedented staging achievement within the SNT.

The author's ambition is to reconstruct the dramaturgical intent of conductor Karel Nedbal and director Bohuš Vilím in Ludovít Hradskýs scenography, which exhibits the clear aesthetic influences of the reformers of Wagner's stage poetics of Adolphe Appia and Alfred Roller. Although expressionist scenography was not an aesthetic sensation in the European production context of 1935, but in the context of the young ensemble of the SNT, it was proof of its artistic ambition and determination. The author considers the possible obstacles and complexities of the staging process, such as the complex conditions of musical preparation, lack of technical equipment for the stage and so on. This text is conceived as an attempt of stage historiography, recognizing the pitfalls of the subjectivity of artistic criticism characteristic of this period.

Štúdia bola zrealizovaná s finančným prispením Literárneho fondu.

Robert Bayer

e-mail: roobertbayer@aol.com

Twitter: @extemporierer 